\title{
THE DYNAMICS OF INTERNATIONAL EQUITY MARKETS IN ASIA, EUROPE AND AMERICA IN TERM OF ECONOMIC GLOBALIZATION
}

\author{
Rana Shahid Imdad Akash¹, Iqbal Mahmood², Kashif Hamid ${ }^{3}$
}

\begin{abstract}
This research explore the cause and effect dynamics of Pakistan Stock Exchange (PSX-100) with the international equity markets from all over the world including 4 from Asia, 3 from Europe and 2 from America for the period starting from January 1, 2006 to July 26, 2018. PSX100 has international investment financial integration with all the markets of Asian, European and American Equity markets. Hang-Seng was showing the cointegration with PSX-100 and provides more opportunities of returns for investors. KLSE and BSX were found to be a cointegration effect; there exist relationship of NASDAQ with PSX-100 and American equity markets. There found Bivariate Causality of S\&P500 with PSX-100 and S\&P500 with IPC. A short run relationship of FTSE with PSX-100 and PSX-100 with IPC exist. The global investment rate of return can have implications to income and economic growth. The economic growth can have best implication for value of assets of the country. This study will support while decision making on escalation process which is dependent on transmission patterns at economic globalization.
\end{abstract}

KEY WORDS: diversification, co integration, portfolio theory, risk and return

JEL:G10

UDC: $336.76(4: 5: 73)$

339.926

COBISS.SR-ID 272162316

\footnotetext{
${ }^{1}$ University of Sargodha, Women Campus, Faisalabad-Pakistan,e-.mail:

shahid.imdad@yahoo.com

${ }^{2}$ Higher Education Department,Govt College of Commerce, Faisalabad , Pakistan,e-mail: iqbal.mehmood@yahoo.com

${ }^{3}$ Faculty Member, University of Agriculture, Faisalabad-Pakistan,e-mail: kashif.boparai@hotmail.com
} 


\section{INTRODUCTION}

The cause and effect at international equity markets are more interested area for international investors. There is a big literature available regarding to risk, volatility, investment opportunity and linkage of equity markets. America and Europ are included in developed equity market and Asia is considered as emerging economies. Cimen (2013) explored the causality analysis of equity markets.

David (2011) documented about the cause and effect relationship of S\&P-500 and FTSE100. There was no effect of HANG SENG and NIKKEI-225. America and Europe are comparatively more stable economies with reference to investment opportunities for investors in international markets. The risk behavior and volatility are less escalated with moments of international equity markets. Asia is considered as emerging markets with higher escalation process due to lower and upper side with volatility of equity markets. Investors are the key players of equity market due to control and right of investment decision making. Investors have country risk while investing in home country. Risk can be reduced through diversified investing into other international countries. International investments can have better implications to utilize best resources and minimize the cost of capital. Idris \& Cheowg (2004) found stochastic trends among equity markets to prove a predictability level and enhanced utilization of information equity prices. The capital markets are also the key concern to outperform due to encouraging savings, utilization and allocating resources for the economic development and growth. This study is used to find the dynamic causal effect of PSX-100 with international markets of Asia, Europe and America. Kim (2005) showed a significant effect on markets in Asia than market of Japan. Ocran (2007) explore to search a dynamic trend and contradicted, Nieh and Yau (2006) also found no long run relationship. Sakthivel and Kamaiah (2012) indicate the relationship of US equity markets and Indian equity markets. Subramanian (2008) studied that East Asian, the five equity markets are cointegrated. Shmiri \& Isa (2010) explored that United States - US equity market has impact on Asia Pacific but have no on Japan. Menon, Subha \& Sagaran (2009) studied about that the STI and NSE both have cointegration effect. Rehman, Zaheer Butt \& Ali (2011) revealed that the equity market in Pakistan had no relation to United Kingdome -UK, United States of America-USA, Taiwan, Singapore and Malaysia and have relation to India, China, Japan and Indonesia. Suchismita \& Mukherjee (2005) analyzed the markets at US which were not showed the co-integration effect to markets at Asia. This study is also an attempt to explain; the economic events at level have cause and effect relation to international equity markets. Ergun $\&$ Nor (2010) supported the dynamic linkages of ISE-Istanbul Stock Exchange and NASDAQ while Europe and Turkey signed a Custom Union agreement. Febrian and Herway (2008) proved that there exist positive signals to trade activities for investors. The causal effect of international equity markets provide positive signal to the investors, because it causes the economic growth and investors can easily know how to minimize the effect of financial crises. The flow of funds from all over the world would be affected by the markets' measures and would provide a place to the investors for introducing new financial products.

\section{DATA \& METHODOLOGY}

This particular study is used to examine the integration and causality relation among the nine equity markets of different region in the world i.e., 4 from Asian equity markets: PSX-100, Hang Seng, KLSE, NIKKI-225;, 3 from European equity markets: CAC-40 FTSE and NASDAQ and 2 from American equity markets: IPC- Mexico and S\&P 500 simultaneously for the period starting from January 1, 2006 to July 26, 2018 using index of daily returns. The return can be calculated on continuous on daily basis as follows: 


$$
R_{t}=\operatorname{Ln}\left(\frac{I P_{t}}{I P_{t-1}}\right)
$$

$R_{t}$ is the return and " $\mathrm{t}$ " is the period, $I P_{t}$ is the end price at current date and $I P_{t-1}$ is the end price at past date. The stationarity of data series through a ADF (Augmented Dickey Fuller -1981) and PP (Philip-Perron test -1988) are applied to test a unit root of series. These can be explained as

$$
y_{\cdot t}=p y_{\cdot t-1}+\varepsilon_{t}
$$

Where $y_{t}$ a dependent variable, $\mathrm{t}$ time length period, $p$ a coefficient and $\varepsilon_{t}$ is the term of error. Three regressions equations for unit root are tested. If there is no constant and trend, then equation as follows:

$$
\Delta y_{\cdot t}=\delta y_{\cdot t-1}+\varepsilon_{t}
$$

If there is constant, $\alpha$ is a constant then equation as follows:

$$
\Delta y_{\cdot t}=\alpha+\delta y_{\cdot t-1}+\varepsilon_{t}
$$

If constant and trend is concerning then equated according to the following:

$$
\Delta \mathrm{y}_{t}=\alpha+\beta \mathrm{etaF}+\delta \mathrm{y}_{t-1}+\varepsilon_{t}
$$

To explore the long term relation, the Johanson and Juselius, 1990 where $\alpha_{0}$ as constant, $\beta_{1}$ as coefficient of $Z_{t}$ and $\varepsilon_{t}$ as error term

$$
\mathrm{y}_{t}=\alpha_{0}+\beta \operatorname{eta}_{1} Z_{t}+\varepsilon_{t}
$$

The cointegration equations, $\lambda_{\text {trace }}$ statistics is used as.

$$
\lambda_{\text {trace }}=-Q \sum_{i=r+1}^{j} \operatorname{Ln}\left(1-\Lambda_{t}\right)
$$

The cointegration equations, Max Eigen value of $\lambda_{\text {Maximum }}$ statistics is used as

$$
\lambda_{\text {Max }}=-\mathcal{Q} \operatorname{Ln}\left(1-\kappa_{t}\right)
$$

Bivariate Autoregressive (Pair wise) process will be used for a particular sample. Particular equation will be used for the determination of long run effect.

$$
\begin{aligned}
& \alpha_{0}+\sum_{i=1}^{n} \mathcal{Q} \omega_{t-1}+\sum_{i=1}^{n} \varkappa_{i} \omega_{t-1}+\varepsilon_{t} \\
& \kappa_{t}=b_{0}+\sum_{i=1}^{n} \mathcal{L}_{i} \kappa_{t-1}+\sum_{i=1}^{n} \kappa_{t} \omega_{t-1}+\varepsilon_{t}
\end{aligned}
$$

Where $\omega_{1}$ and $\omega_{2}$ are based on the assumption about the two series have not been cointegrated and $\Delta$ indicated at first difference. If both the series are to be cointegrated then an additional test would be applied for error correction model. The suitable test for the series will be used as follows.

$$
\Delta \omega_{2 t}=b_{0}+\delta_{2}\left(\omega_{1 t-1}-\mathcal{L} \omega_{2 t-1}\right) \sum_{i=1}^{n} b_{1 i} \Delta \omega_{1 t-i}+\sum_{i=1}^{n} b_{2 i} \Delta \omega_{2 t-i}+\varepsilon_{2 t}
$$

To find out the relationship between $\omega_{1}$ and $\omega_{2}$, the term $\omega_{1 t-1}-\mathcal{L} \omega_{2 t-1}$ is a term of an error correction term.

\section{EMPIRICAL RESULTS}

ADF (Augmented Dickey Fuller) and PP (Philip Perron Test) are the tests of stationary. Table-1, the results indicates that the Asia, Europe and America equity markets were reflecting stationarity of data at level. 
Table 1: ADF and PP Tests

\begin{tabular}{|l|c|c|}
\hline Equity Markets & $\begin{array}{c}\text { Augmented Dickey Fuller } \\
\text { Test at Level of 5\% }\end{array}$ & $\begin{array}{c}\text { Philip - Perron } \\
\text { Test at Level }\end{array}$ \\
\hline PSX-100 & -50.6523 & -51.798 \\
\hline Hang Seng & -56.5083 & -56.509 \\
\hline KLSE & -61.2125 & -61.0119 \\
\hline NIKKIE-225 & -57.2613 & -57.4502 \\
\hline CAC-40 & -27.2866 & -57.9332 \\
\hline FTSE-100 & -26.7592 & -58.651 \\
\hline NASDAQ & -42.6144 & -58.0078 \\
\hline IPC & -39.7887 & -50.6455 \\
\hline S\&P 500 & -43.8304 & -61.3499 \\
\hline
\end{tabular}

Table 2: Critical Values

\begin{tabular}{|l|l|l|l|}
\hline Probabilities & $\mathbf{1 \%}$ & $\mathbf{5 \%}$ & $\mathbf{1 0 \%}$ \\
\hline ADF at Level & -3.43228 & -2.86228 & -2.56721 \\
\hline PP at Level & -3.43228 & -2.86228 & -2.56721 \\
\hline
\end{tabular}

Table 3 reveals that the results of Johanson cointegration of Trace Statistics of equity markets of Asia, Europe and America. A co integration relation exist due to each series of returns trace statistics values $>$ critical values.

Table 3: Johanson Multivariate Cointegration of Asian, European, American Equity Market (Trace Statistics)

\begin{tabular}{|c|c|c|c|c|c|}
\hline $\begin{array}{l}\text { Equity } \\
\text { Markets. }\end{array}$ & $\begin{array}{l}\text { Hypothesis } \\
\text { No. of CE(s) }\end{array}$ & $\begin{array}{l}\text { Eigen } \\
\text { Value }\end{array}$ & $\begin{array}{l}\text { Trace } \\
\text { Statistic }\end{array}$ & $\begin{array}{l}\text { At 5\% } \\
\text { Critical } \\
\text { Value }\end{array}$ & Critical Remarks \\
\hline \multicolumn{5}{|c|}{ PSX-100 WITH ASIAN EQUITY MARKETS. } & \multirow{5}{*}{$\begin{array}{l}\text { In this there exist } 4 \text { Co- } \\
\text { Integration Vector at } \\
\text { Critical level of } 5 \% \text {. }\end{array}$} \\
\hline PSX-100 & None & 0.2248 & 7410.6650 & NA & \\
\hline Hang Seng & At most $4 *$ & 0.1887 & 4442.3630 & 197.3709 & \\
\hline KLSE & At most $6 *$ & 0.1751 & 3171.3630 & 125.6154 & \\
\hline NIKKIE-225 & At most 8 . & 0.1533 & 2009.7190 & 69.8189 & \\
\hline \multicolumn{5}{|c|}{ PSX-100 WITH EUROPE EQUITY MARKETS. } & \multirow{5}{*}{$\begin{array}{l}\text { In this there exist } 4 \text { Co- } \\
\text { Integration Vector at } \\
\text { Critical level of } 5 \% \text {. }\end{array}$} \\
\hline PSX-100 & None * & 0.2767 & 5287.7940 & 159.5297 & \\
\hline$\overline{\mathrm{CAC}-40}$ & At most $3^{*}$ & 0.1991 & 2666.9890 & 69.8189 & \\
\hline FTSE-100 & At most $4 *$ & 0.1744 & 1981.6750 & 47.8561 & \\
\hline NASDAQ & At most $5 *$ & 0.1648 & 1390.1690 & 29.7971 & \\
\hline \multicolumn{5}{|c|}{ PSX-100 WITH AMERICAN EQUITY MARKETS. } & \multirow{4}{*}{$\begin{array}{l}\text { In this there exist } 3 \text { Co- } \\
\text { Integration Vector at } \\
\text { Critical level of } 5 \% \text {. }\end{array}$} \\
\hline PSX-100 & None* & 0.2023 & 1754.2600 & 29.7971 & \\
\hline$\overline{\mathrm{IPC}}$ & At most $1^{*}$ & 0.1772 & 1056.4610 & 15.4947 & \\
\hline S\&P 500 & At most $2 *$ & 0.1369 & 454.5332 & 3.8415 & \\
\hline
\end{tabular}

PSX-100 also have co-integration relation with the other markets at Asia due to its trace statistics $>$ critical value at 5\% significance level. Table 3 also resulted that European equity 
markets trace statistics > critical value at 5\%. It is revealed that there is an existence of 8 trace statistics cointegration vector. All the equity markets of Europe have cause and effect with each other due to cointegration relationship of equity markets of Europe. PSX-100 has also integration with markets at Europe and America, which is a positive signal to diversify the risk of investor while decisions of investments.

Table 4: Johanson Multivariate Cointegration of Asia Pacific, European and American Equity Markets (Maximum Eigen Value)

\begin{tabular}{|c|c|c|c|c|c|}
\hline $\begin{array}{l}\text { Equity } \\
\text { Markets. }\end{array}$ & $\begin{array}{l}\text { Hypothesis } \\
\text { No. of CE(s) }\end{array}$ & $\begin{array}{l}\text { Eigen } \\
\text { Value }\end{array}$ & $\begin{array}{l}\text { Max. Eigen } \\
\text { Value } \\
\text { Statistics. }\end{array}$ & $\begin{array}{l}5 \% \\
\text { Critical } \\
\text { Value }\end{array}$ & Critical Remarks \\
\hline \multicolumn{6}{|c|}{ PSX-100 WITH ASIAN EQUITY MARKETS. } \\
\hline PSX-100 & None & 0.2248 & 786.1318 & NA & \multirow{4}{*}{$\begin{array}{l}\text { In this there exist } 4 \text { Co- } \\
\text { Integration Vector at Critical } \\
\text { level of } 5 \% .\end{array}$} \\
\hline Hang Seng & At most $4 *$ & 0.1887 & 645.3889 & 58.4335 & \\
\hline KLSE & At most $6^{*}$ & 0.1751 & 594.0677 & 46.2314 & \\
\hline NIKKIE-225 & At most $8 *$ & 0.1533 & 513.6672 & 33.8769 & \\
\hline \multicolumn{6}{|c|}{ PSX-100 WITH EUROP EQUITY MARKETS. } \\
\hline PSX-100 & None & 0.2248 & 786.1318 & NA & \multirow{4}{*}{$\begin{array}{l}\text { In this there exist } 4 \text { Co- } \\
\text { Integration Vector at Critical } \\
\text { level of } 5 \% \text {. }\end{array}$} \\
\hline CAC-40 & At most $3 *$ & 0.1996 & 687.3794 & 64.5047 & \\
\hline FTSE-100 & At most $4 *$ & 0.1887 & 645.3889 & 58.4335 & \\
\hline NASDAQ & At most $5 *$ & 0.1834 & 625.6118 & 52.3626 & \\
\hline \multicolumn{6}{|c|}{ PSX-100 WITH AMERICA EQUITY MARKETS. } \\
\hline PSX-100 & None * & 0.2023 & 697.7993 & 21.1316 & \multirow{3}{*}{$\begin{array}{l}\text { In this there exist } 2 \text { Co- } \\
\text { Integration Vector at Critical } \\
\text { level of } 5 \% \text {. }\end{array}$} \\
\hline IPC & At most $1 *$ & 0.1772 & 601.9275 & 14.2646 & \\
\hline S\&P 500 & At most $2 *$ & 0.1369 & 454.5332 & 3.8415 & \\
\hline
\end{tabular}

Table 4 indicates the existence of 10 co-integration maximum eigen value statistics $>$ at $5 \%$ critical level, suggesting that the investors can have implication to enhance the activities of trade with diversified decision. The Bivariate test of cointegration of PSX-100 with markets at Europe revealed that PSX-100 was cointegrated with equity markets at Europe and European equity markets were also cointegrated with each other, which reveals that there exists a long term integration relation of PSX-100 with other international equity markets.

Table 5: Bivariate Cointegration for PSX-100 with Asia, Europe and America:

\begin{tabular}{|c|l|l|l|l|c|}
\hline Equity Markets. & Hypothesis & $\begin{array}{c}\text { Eigen } \\
\text { Value }\end{array}$ & $\begin{array}{c}\text { Trace } \\
\text { Statistics. }\end{array}$ & $\begin{array}{c}\text { At 5\% } \\
\text { Critical } \\
\text { Value }\end{array}$ & $\begin{array}{c}\text { Critical } \\
\text { Remarks. }\end{array}$ \\
\hline PSX-100 WITH ASIAN EQUITY MARKETS. \\
\hline PSX-100 -Hang Seng & None * & 0.1849 & 1102.4990 & 15.4947 & $\begin{array}{c}\text { Co-integration } \\
\text { Exist. }\end{array}$ \\
\hline
\end{tabular}




\begin{tabular}{|c|c|c|c|c|c|}
\hline PSX-100-KLSE & $\begin{array}{l}\text { None } * \\
\text { At most } 1 *\end{array}$ & $\begin{array}{l}0.1695 \\
0.1392\end{array}$ & $\begin{array}{l}1036.0840 \\
462.6470\end{array}$ & $\begin{array}{l}15.4947 \\
3.8415\end{array}$ & $\begin{array}{c}\text { Co-integration } \\
\text { Exist. }\end{array}$ \\
\hline PSX-100 -NIKKIE-225 & $\begin{array}{l}\text { None } * \\
\text { At most } 1 *\end{array}$ & $\begin{array}{l}0.1897 \\
0.1404\end{array}$ & $\begin{array}{l}1116.7170 \\
467.1962\end{array}$ & $\begin{array}{l}15.4947 \\
3.8415\end{array}$ & $\begin{array}{c}\text { Co-integration } \\
\text { Exist. }\end{array}$ \\
\hline \multicolumn{6}{|c|}{ PSX-100 WITH EUROPEAN EQUITY MARKETS } \\
\hline PSX-100 -FTSE-100 & $\begin{array}{l}\text { None } * \\
\text { At most } 1 *\end{array}$ & $\begin{array}{l}0.1960 \\
0.1388\end{array}$ & $\begin{array}{l}1134.6640 \\
461.3684\end{array}$ & $\begin{array}{l}15.4947 \\
3.8415\end{array}$ & $\begin{array}{c}\text { Co-integration } \\
\text { Exist. }\end{array}$ \\
\hline PSX-100 -NASDAQ & $\begin{array}{l}\text { None } * \\
\text { At most } 1 *\end{array}$ & $\begin{array}{l}0.1869 \\
0.1393\end{array}$ & $\begin{array}{l}1101.7220 \\
463.0010\end{array}$ & $\begin{array}{l}15.4947 \\
3.8415\end{array}$ & $\begin{array}{c}\text { Co-integration } \\
\text { Exist. }\end{array}$ \\
\hline \multicolumn{6}{|c|}{ PSX-100 WITH AMERICAN EQUITY MARKETS } \\
\hline PSX-100-IPC & $\begin{array}{l}\text { None } * \\
\text { At most } 1 *\end{array}$ & $\begin{array}{l}0.1840 \\
0.1396\end{array}$ & $\begin{array}{l}1092.0760 \\
464.2516\end{array}$ & $\begin{array}{l}15.4947 \\
3.8415\end{array}$ & $\begin{array}{c}\text { Co-integration } \\
\text { Exist. }\end{array}$ \\
\hline PSX-100 -S\&P 500 & $\begin{array}{l}\text { None } * \\
\text { At most } 1 *\end{array}$ & $\begin{array}{l}0.1920 \\
0.1414\end{array}$ & $\begin{array}{l}1128.7380 \\
470.6083\end{array}$ & $\begin{array}{l}15.4947 \\
3.8415\end{array}$ & $\begin{array}{c}\text { Co-integration } \\
\text { Exist. }\end{array}$ \\
\hline
\end{tabular}

There also found to be a short run relationship of NIKKEI-225 with KLSE at lag length 1 and with Hang Seng at lag length 2. In short the overall results reveal that there exist short run relationships of PSX-100 with equity markets of Asia. Further analysis indicates the results of Vector Error Correction Model of PSX-100 with European equity markets in table 5. There found short run relationship FTSE at lag length 1 and with KSE-100, CAC-40 at lag length 2. There also found short run relationship of CAC-40 with NASDAQ at lag 1. FTSE has also short run relationship with CAC-40 and NASDAQ at lag 1 and with CAC-40 at lag length 2. NASDAQ with CAC-40 at lag 1 and with KSE-100 and CAC-40 at lag 2. So Overall result indicates that European markets have short run relationship with each other but KSE-100 has only with ATX. Table 5 reveals the result of Vector Error Correction Model of KSE-100 with American Equity Markets. Results indicate that there exist short run relationship of KSE-100 with IPC and S\&p500 both the markets of America at lag 1 and with S\&P500 at lag 2.

Table 5: Vector Error Correction Model of PSX with Europe Markets

\begin{tabular}{||l|l|l|l|l|}
\hline \multicolumn{2}{||}{ PSX-100 WITH ASIAN EQUITY MARKETS } \\
\hline \hline & D(KSE-100) & D(HangS) & D(KLSE) & $\begin{array}{l}\text { D(Nikkei- } \\
\text { 225) }\end{array}$ \\
\hline Error Correction: & {$[-0.64850]$} & {$[-0.48123]$} & {$[16.4409]$} & {$[6.68782]$} \\
\hline CointEq1 & {$[-0.47565]$} & {$[-2.08600]$} & {$[-23.5071]$} & {$[2.56396]$} \\
\hline D(KLSE(-1)) & {$[0.07650]$} & {$[-2.05764]$} & {$[-13.8331]$} & {$[2.68436]$} \\
\hline D(NLSE(-2)) & {$[-1.69278]$} & {$[-0.54234]$} & {$[3.53395]$} & {$[-35.8691]$} \\
\hline D(Nikkei-225(-1)) & {$[-0.47484]$} & {$[2.52178]$} & {$[1.60140]$} & {$[-19.0991]$} \\
\hline \hline PSX-100 WITH EUROPEAN EQUITY MARKETS & & \\
\hline CointEq1 & {$[-0.31564]$} & {$[45.0468]$} & {$[4.08932]$} & {$[-3.93049]$} \\
\hline D(CAC-40(-1)) & {$[-1.09005]$} & {$[0.34200]$} & {$[0.50949]$} & {$[-2.26376]$} \\
\hline D(CAC-40(-2)) & {$[-1.29488]$} & {$[-0.66151]$} & {$[0.25311]$} & {$[-1.65821]$} \\
\hline D(FTSE(-1)) & {$[0.08779]$} & {$[9.32668]$} & {$[-37.5583]$} & {$[-2.12225]$} \\
\hline
\end{tabular}




\begin{tabular}{|c|c|c|c|c|}
\hline D(FTSE(-2)) & {$[0.00052]$} & [ 6.31295] & {$[-17.2656]$} & {$[-1.09319]$} \\
\hline D(NASDAQ(-1)) & [0.60557] & {$[-10.2347]$} & [0.23941] & {$[-37.9762]$} \\
\hline D(NASDAQ(-2)) & [ 2.29471] & {$[-2.81678]$} & {$[0.07260]$} & {$[-21.3533]$} \\
\hline \multicolumn{5}{|c|}{ PSX-100 WITH AMERICAN EQUITY MARKETS } \\
\hline CointEq1 & & [-3.73681] & {$[-8.72476]$} & [32.1107] \\
\hline D(Kse-100(-1)) & & {$[-35.1226]$} & [ 2.77093] & {$[-4.37744]$} \\
\hline D(Kse-100(-2)) & & {$[-18.3914]$} & [ 0.98587] & {$[-2.83576]$} \\
\hline $\mathrm{D}(\mathrm{IPC}(-1))$ & & [ 1.38912] & {$[-29.5730]$} & [-11.7518] \\
\hline $\mathrm{D}(\mathrm{IPC}(-2))$ & & {$[0.19080]$} & {$[-18.2801]$} & [-4.67307] \\
\hline D(S\&P500(-1)) & & {$[-3.35566]$} & [-6.28635] & {$[-0.05460]$} \\
\hline D(S\&P500(-2)) & & {$[-1.11269]$} & [-3.07494] & [-2.07177] \\
\hline \multirow[t]{3}{*}{ C } & & 0.000 & 0.000 & 0.000 \\
\hline & & 0.000 & 0.000 & 0.000 \\
\hline & & {$[-0.06024]$} & [0.02340] & {$[-0.00317]$} \\
\hline
\end{tabular}

IPC has short run lead lag relationship with S\&P500 at lag 1 and 2. S\&P500 also found to be as a short run relationship with KSE-100, IPC at lag 1 and with IPC at lag 2. So in short all three regions of equity markets has the lead lag short run relationship which is a positive signal for the investor to enhance the trading activities and for diversification decisions.

\section{CONCLUSION}

In this study of cointegration in economic globalization perspective of Asia, Europe and America stock markets, PSX-100 is risky as concern to other equity markets. As for as this rational in finance is concerned, more risk more return and vice versa, is reflected in the results of this study. The equity markets in Asia are more risky as compared to Europe and America because of positive return. Overall analysis revealed that there exists a long run and short run relationship of equity markets with each other in Asia, Europe and America. This will create a positive signal for the investor to happen the trade activities for diversification decisions. The international trade is used for financial integration at global level. The dynamics of economic globalization will proceeds the growth and linkage dependency among international due to long term complex implication. The globalization as a cross border financial integration concerned to international trade flow and foreign direct investments (FDI). The trade flows and FDI with proportion of GDP contributes to capital invested at international level. The favorable situation of taxes, labour cost, tariffs, control over capital due to financial integration lead to down in exchange rate. The decline in currency may improve the trade and growth patterns. However, international financial markets transmission patterns are seems to be a relevant process. Therefore, PSX100 as Asia pacific equity market is providing space to the investors to perform better.

\section{REFERENCES}

[1]Cimen, A. (2013). Causality analysis of stock markets: An application for Istanbul Stock Exchange, Interdisciplinary Journal of Contemporary Research in business, 4:12, pp. 124-132.

[2]David, N. B. (2011). Causality Among New York. London. Tokyo and Hong Kong Stock Markets, Australian Journal of Business and Management Research, 1:4, pp.122-131.

[3] Engle, R.F. and Granger, C.W.J. (1987). Co-Integration, error correction: 
Representation, estimation and testing, Econometrica, 55:2, pp. 251-276.

[4]Ugur, E. \& Nor, A. H. (2010). The Stock Market Relationship between Turkey and the United States Under Unionization, Asian Academy of Management, Journal of Accounting and Finance, 6 (2), pp.19-33.

[5]Febrian, E. and Herwany,A. (2008). Co-integration and Causality Among Jakarta Stock Exchange, Singapore Stock Exchange, and Kuala Lumpur Stock Exchange, Munich Personal RePEc Archive, Paper No. 9637.

[6]Granger, C.W.J. (1988). Some recent developments in a concept of causality, Journal of Econometrics, 39:1/2, pp. 199-211.

[7]Hansda, S. K. \& Ray, P. (2003). Stock Market Integration and Dually

Listed Stocks: Indian ADR and Domestic Stock Prices, Economic and Political Weekly, 12:3, pp.741-753.

[8]Idris, F. and Cheowg, T.T. (2004). Inter - counter linkage in Kuala

Lumpur stock exchange return, The Survey college journal, pp. 21-27.

[9]Johansen, S. and Juselius, K. (1990). Maximum likelihood estimation and

inference on cointegration with application to the demand for money, Oxford Bulletin of Economics and Statistics, 52. pp. 169-210.

[10]Kim, S. (2005). Information Leadership in the Advanced Asia-Pacific Stock Markets: Return, Volatility, and Volume Information Spillovers from the US and Japan, Journal of the Japanese and International Economies, 19:3, pp. 338-365.

[11]Menon, R. N., Subha, V. M. and Sagaran, S. (2009). Cointegration of

Indian stock markets with other leading stock markets, Studies in Economics and Finance, 26:2, pp. 87- 94.

[12]Ocran, K, M. (2007). Interrelation among stock prices of South Africa and the United States and the rand/doller exchange rate, Journal of international money and finance, pp.1-13.

[13]Rehman, U.K, Butt, Z.B and Ali, K. (2011).Co movement between Emerging and Developed Stock Markets: An Investigation through Cointegration Analysis, World Applied Sciences Journal, 12:4, pp 395-403.

[14]Sakthivel, P, Kamaiah, B. (2012). Interlinkages among Asian, European and the U.S Stock Markets: A Multivariate Cointegration Analysis, Journal of Economics and Behavioral Studies, 4:3, pp. 129-141.

[15]Shamiri, A. and Isa, Z. (2010). Volatility transmission: what do Asia Pacific markets expect?, Studies in Economics and Finance, 27:4, pp. 299- 313.

[16]Subramanian, U. (2008). Cointegration of Stock Markets in East Asia, European Journal of Economics, Finance and Administrative Sciences, 14,ISSN 1450-2275.

[17]Suchismita, B. \& Paramita, M. (2005). A Study of Interlikings between the Indian Stock Market and other Emerging and Developed Market. World Economic Outlook, IMF, pp.1-13.

\section{Article history:}

- Received 30 October 2018

- Accepted 12 December 2018 